\title{
PENDAMPINGAN PERINTISAN USAHA BUMDES UNTUK PEMBERDAYAAN EKONOMI MASYARAKAT DESA PETELUAN INDAH
}

\section{Establishment Of Bumdes Business Development For Community Economic Empowerment In Peteluan Indah Village}

\author{
Lilik Handajani* ${ }^{*}$, Zaenal Abidin, Endar Pituringsih \\ 1)Program Studi Magister Akuntansi, Universitas Mataram \\ Jalan Majapahit Nomor 62 Kota Mataram
}

*Alamat korespondensi: lilikhandajani@unram.ac.id

(Tanggal Submission: 24 November 2020, Tanggal Accepted : 17 April 2020)

\begin{abstract}
Keyword: Abstract :
BUMDes, potensi

desa, pemberdaya an ekonomi, desa Peteluan Indah Pengelolaan badan usaha milik desa (BUMDes) seringkali mengalami berbagai hambatan yang disebabkan oleh berbagai faktor antara lain pengetahuan, pemahaman serta kemampuan SDM pengelola yang relatif rendah, pemilihan usaha BUMDes yang kurang mempertimbangkan potensi keunggulan desa dan kurangnya keterlibatan masyarakat desa dalam menyampaikan aspirasi yang positif. Hal tersebut menyebabkan BUMDes tidak dapat memajukan ekonomi masyarakat desa dengan maksimal. Kegiatan pengabdian kepada masyarakat ini bertujuan untuk memberikan pengetahuan dan pemahaman bagi para pemangku kepentingan desa tentang pembentukan BUMDes yang sesuai dengan kebutuhan dan potensi yang dimiliki oleh desa, mengidentifikasi potensi yang dimiliki desa dan merumuskan bentuk-bentuk usaha yang dapat dilakukan melalui BUMDes serta menginventarisasi rancangan usaha (business plan) prioritas rintisan BUMDes yang berpeluang untuk ditindaklanjuti sebagai usaha BUMDes pada desa Peteluan Indah. Metode pelaksanaan kegiatan ini adalah dengan melakukan survey, diskusi (FGD) dalam forum pertemuan desa dan perumusan rencana (kerja) usaha. Selain dapat dapat meningkatkan pengetahuan dan pemahaman pemangku kepentingan terhadap pembentukan BUMDEs, hasil kegiatan ini dapat mengidentifikasi bentuk usaha BUMDes yang sesuai dengan potensi unggulan desa dan merumuskan prioritas rencana bisnis BUMDes. Rancangan usaha BUMDes yang telah mengakomodir aspirasi masyarakat dan potensi desa tersebut dapat memetakan potret desa secara lebih nyata sehingga direkomendasikan dapat ditindaklanjuti dan diimplementasikan sebagai usaha ekonomi produktif yang bermanfaat dalam meningkatkan pemberdayaan ekonomi masyarakat desa.
\end{abstract}

Panduan sitasi / Citation guidance (APPA $7^{\text {th }}$ edition):

Handajani, L., Abidin, Z., \& Pituringsih, E. (2021). Pendampingan Perintisan Usaha Bumdes Untuk Pemberdayaan Ekonomi Masyarakat Desa Peteluan Indah. Jurnal Abdi Insani Universitas Mataram, 8 (1), 10-17. http://doi.org/10.29303/abdiinsani.v8i1.362 


\section{PENDAHULUAN}

Desa merupakan tingkatan penyelenggaraan pemerintahan pada level terbawah dituntut untuk mampu melakukan pemberdayaan ekonomi untuk kesejahteraan masyarakat desanya. Sejak Undang-Undang Nomor 6 tahun 2014 tentang desa disahkan maka desa memiliki kewenangan untuk membangun desa. Keberadaan regulasi tersebut menjadi momentum yang mendorong terciptanya tata kelola desa yang lebih transparan, akuntabel, serta masyarakat desa yang partisipatif dan perekonomian desa yang menghidupi (Purnamasari, 2016). Hal ini tidak terlepas dari besarnya dana yang digelontorkan oleh pemerintah pusat ke desa melalui mekanisme dana desa, sehingga tersedia sumberdaya finansial yang bisa digunakan untuk mengembangkan peluang usaha, yang salah satunya melalui pembentukan badan usaha milik desa (BUMDes). Peran BUMDes diharapkan menjadi peluang usaha sebagai salah satu sumber penerimaan desa yang dapat digunakan untuk meningkatkan perekonomian masyarakat desa. Keberadaan BUMDes membawa perubahan yang signifikan bagi peningkatan kesejahteraan masyarakat secara langsung serta memberikan dampak positif ekonomi dan sosial yang signifikan bagi penduduk desa (Setyobakti, 2017). BUMDEs ini merupakan salah satu lembaga di desa yang bergerak di bidang sosial dan ekonomi dalam memberikan layanan terhadap masyarakat desa terutama bidang usaha sebagai penguatan ekonomi desa (Ramadana, 2013). Data Kementerian Desa dan Daerah Tertinggal (2018) menunjukkan bahwa sampai pertengahan tahun 2018 jumlah BUMDes telah mencapai 35.000 dari 74.910 desa yang ada di Indonesia. Hal ini menunjukkan bahwa BUMDes menjadi peluang usaha ekonomi sekaligus tantangan bagi desa dalam merencanakan dan mengimplementasikannya.

Pendirian BUMDES sebaiknya direncanakan dengan matang terkait jenis usaha yang akan dilakukan dan mekanisme pengelolaannya sehingga benar-benar dapat bermanfaat sebagai suatu usaha ekonomi produktif untuk meningkatkan perekonomian desa dan masyarakat secara luas. Namun demikian banyak juga desa yang gagal dalam menjalankan BUMDes karena kurang siapnya desa, potensi desa yang minim, jenis usaha yang terbatas, pengetahuan sumberdaya pengelola serta partisipasi masyarakat yang rendah (Agunggunanto dkk, 2016). Agar BUMDes menjadi sustainable maka perlu peningkatan sarana prasarana, inovasi produk yang dihasilkan, mengembangkan jaringan distribusi produk, serta pelatihan SDM secara berkala dan budaya organisasi yang baik (Rahmawati, 2020). Untuk menjadi lembaga usaha desa yang mandiri, pembentukan BUMDes harus ditindaklanjuti dengan serangkaian mekanisme kegiatan untuk mengembangnya dan tidak hanya berhenti sampai pembentukannya saja (Anggareni, 2016). Perancangan usaha (business plan) BUMDes juga harus melibatkan seluruh komponen masyarakat dan perangkat desa, seperti kepala desa, BPD, kelompok pemuda, serta masyarakat melalui musyawarah desa. Namun demikian, faktanya banyak BUMDes yang hanya dibentuk saja tetapi usahanya tidak berjalan sebagaimana mestinya. Hal ini karena dalam pembentukan BUMDes, aspirasi dan kebutuhan masyarakat serta potensi yang ada di desa belum menjadi pertimbangan utama dalam pembentukan maupun pengembangan usaha BUMDes. Pembentukan BUMDEs juga memiliki tantangan untuk menentukan bentuk usaha yang tepat sesuai dengan potensi yang dominan yang dimiliki desa. Kondisi ini tentu saja menjadi permasalahan yang harus dicarikan solusinya sehingga diperlukan upaya nyata untuk mewujudkan rancangan usaha BUMDes yang berperan untuk meningkatkan kesejahteraan bagi masyarakat desa.

Keterbatasan dalam merumuskan rencana usaha bagi BUMDes menjadi masalah bagi sebagian besar desa, tidak terkecuali desa Peteluan Indah yang berada di Kecamatan Lingsar 
Kabupaten Lombok Barat. Hal ini karena relatif terbatasnya pemahaman dan pengetahuan yang dimiliki oleh pemangku kepentingan desa, seperti kepala desa dan perangkat, BPD, pengelola BUMDes dan masyarakat, tentang bisnis dan pengelolaan BUMDes. Hasil survei pendahuluan (preliminary survey) pada desa Peteluan Indah mengungkap masih rendahnya pengetahuan dan pemahaman dari kepala desa dan perangkat desa serta masyarakat secara umum tentang pengelolaan BUMDes. Kendala terutama berkaitan kesulitan dalam menentukan kegiatan BUMDes yang cocok dan sesuai dengan potensi yang dimiliki oleh desa. Oleh karenanya, ketika BUMDes dapat dikelola dengan berdasarkan potensi unggulan yang dimiliki desa maka peran BUMDes sebagai badan usaha penghasil pendapatan yang dimiliki desa dapat dioptimalkan untuk pemberdayaan ekonomi masyarakat (Anggareni, 2016). Tahapan pengelolaan badan usaha BUMDes dimulai dari perencanaan, pengamatan, penataan dan seleksi, pemeliharaan dan pelaporan (Ariyanto, 2019). Untuk menunjang tercapainya tujuan tersebut maka diperlukan upaya-upaya untuk membantu dan mendampingi desa Peteluan Indah dalam mengindentifikasi dan menginventarisasi rancangan peluang usaha dan perencanaan rintisan BUMDes yang sejalan dengan kebutuhan masyarakat dan pengelolaan potensi yang dimiliki desa.

Tujuan kegiatan pengabdian kepada masyarakat ini adalah memberikan pengetahuan dan pemahaman bagi para pemangku kepentingan desa tentang pembentukan BUMDes sesuai dengan kebutuhan dan potensi yang dimiliki oleh desa, mengidentifikasi potensi yang dimiliki desa dan merumuskan kegiatan-kegiatan usaha yang dapat dilakukan melalui BUMDes serta menginventarisasi rancangan usaha (business plan) prioritas pengelolaan rintisan BUMDes yang berpeluang untuk ditindaklanjuti sebagai usaha BUMDes pada desa Peteluan Indah. Hasil dari kegiatan pengabdian masyarakat kemitraan ini memberikan manfaat peningkatan pengetahuan dan pemahaman para pemangku kepentingan desa dan masyarakat desa tentang pengelolaan BUMDes. Dengan demikian rancangan usaha BUMDes berbasis kebutuhan dan pengembangan potensi desa yang terbentuk dapat bermanfaat bagi pemberdayaan ekonomi masyarakat dapat ditindaklanjuti oleh desa untuk diimplementasikan.

\section{METODE KEGIATAN}

Kegiatan pengabdian masyarakat kemitraan ini dimulai dengan menemukan masalah, pelaksanaan kegiatan dan solusi pemecahan masalah yang dilakukan melalui beberapa tahapan sebagai berikut :

1. Pertemuan pendahuluan

Kegiatan dimulai dengan melakukan pertemuan pendahuluan dengan Kepada Desa dan perangkat desa untuk memperoleh persepsi yang sama tentang tujuan kegiatan pengabdian masyarakat kemitraan dalam rangka membantu desa Peteluan Indah untuk merumuskan rencana usaha pembentukan rintisan BUMDes yang sesuai dengan potensi unggulan yang dimiliki desa.

2. Menggali kebutuhan dan potensi BUMDes

Tahap berikutnya adalah untuk menggali kebutuhan masyarakat terhadap potensi BUMDes yang dilakukan dengan cara melakukan survey melalui penyebaran kuisioner serta wawancara kepada pemangku kepentingan desa, seperti kepala desa dan perangkat desa, Badan Permusyawaratan Desa (BPD), Kelompok pemuda/karang taruna, perwakilan Lembaga Ketahanan Masyarakat Desa (LKMD), pengelola BUMDes, kawil/kadus dan perwakilan 
masyarakat.

3. Inventarisasi hasil survey

Dari hasil survey dapat diinventarisasi bentuk-bentuk kegiatan usaha BUMDes sesuai dengan potensi unggulan yang dimilliki desa dan mengakomodir keinginan dan kebutuhan masyarakat desa.

4. Forum pertemuan musyawarah desa

Hasil dari rancangan usaha BUMDes selanjutnya disampaikan dan didiskusikan dalam suatu forum pertemuan musyawarah desa atau musyawarah perencanaan pembangunan desa untuk mendapatkan masukan, saran dan pertimbangan dari para pemangku kepentingan desa dan masyarakat.

5. Inventarisasi rancangan usaha BUMDes

Tahap akhir dari kegiatan pengabdian masyarakat kemitraan ini adalah menginventarisasi prioritas rancangan usaha rintisan BUMDes dan memberikan rekomendasi pelaksanaannya sehingga dapat ditindaklanjuti dalam menjalankan usaha BUMDes.

\section{HASIL DAN PEMBAHASAN}

Sesuai dengan tujuan penelitian, pada bagian ini menyajikan hasil dan pembahasan dari kegiatan pengabdian masyarakat mulai dari memberikan pengetahuan dan pemahaman tentang pembentukan BUMDes, identifikasi potensi desa dan kebutuhan masyarakat serta perumusan kegiatan-kegiatan usaha prioritas yang dilakukan melalui BUMDes.

\section{Pengetahuan dan Pemahaman Pemangku Kepentingan Terhadap Pembentukan BUMDes}

Untuk mengetahui sejauhmana pemahaman dan pengetahuan tentang BUMDes serta tujuan pendiriannya maka dilakukan preliminary survey melalui pengisian kuisioner dan wawancara awal kepada para pemangku kepentingan desa seperti kepala desa dan perangkat desa, Badan Permusyawaratan Desa (BPD), kelompok pemuda, kepada dusun dan kepala wilayah (Kawil), pengelola BUMDes dan masyarakat. Kuisoner mengggali informasi tentang pengetahuan dan manfaat BUMDes serta pihak yang perlu dilibatkan dalam pengelolaan BUMDes. Hasil dari tahapan ini menunjukkan bahwa hampir semua pemangku kepentingan desa dan masyarakat sudah memahami tentang BUMDes dan mengetahui manfaat keberadaan BUMDes bagi masyarakat. Mereka menyatakan bahwa dengan BUMDes akan bisa memberikan kesejahteraan masyarakat, meningkatkan perputaran ekonomi desa dan meningkatkan pendapatan desa. Lebih dari $90 \%$ pemangku kepentingan desa menginginkan pembentukan dan pengembangan usaha BUMDes. Hasil dari tahapan ini juga mengungkapkan bahwa pembentukan dan pengelolaan BUMDEs terutama harus didukung dan melibatkan masyarakat, kelompok pemuda /karang taruna, peran dari kepala desa dan aparat desa, Badan Permusyawaratan Desa (BPD) dan Lembaga Ketahanan Masyarakat Desa (LKMD). Dengan menyerap aspirasi pimpinan desa dan perwakilan kelompok masyarakat dapat dinyatakan bahwa pembentukan usaha BUMDes di Desa Peteluan Indah berpeluang untuk dilakukan.

\section{Identifikasi Potensi Desa dan Kebutuhan Masyarakat}

Keberhasilan BUMDes ditentukan oleh kemampuan dalam mengidentifikasi bentuk usaha BUMDes yang tepat yang sesuai dengan potensi yang dimiliki desa dan kebutuhan masyarakat. Faktor lain yang mendorong keberhasilan pelaksanaannya adalah adanya pengetahuan dan pemahaman 
yang memadai pengelola BUMDes dalam menjalankan kegiatan operasional BUMDes yang didukung oleh kemampuan manajemen usaha dan pertanggungjawaban pengelolaan keuangan yang baik. Untuk mencapai tujuan tersebut maka dalam kegiatan pengabdian ini dilakukan penyebaran kuisioner dan diskusi untuk mengidentifikasi potensi desa dan bentuk usaha BUMDes yang didukung keberadaannya oleh pemangku kepentingan desa dan masyarakat. Hasil dari kegiatan selanjutnya untuk dibahas sebagai salah satu agenda pada pertemuan musyawarah desa (Musdes) atau musyawarah perencanaan pembangunan desa (Musrenbangdes) untuk mendapatkan masukan dan pertimbangan dari semua pemangku kepentingan desa yang diharapkan sehingga menjadi program kerja desa yang didukung oleh semua masyarakat.

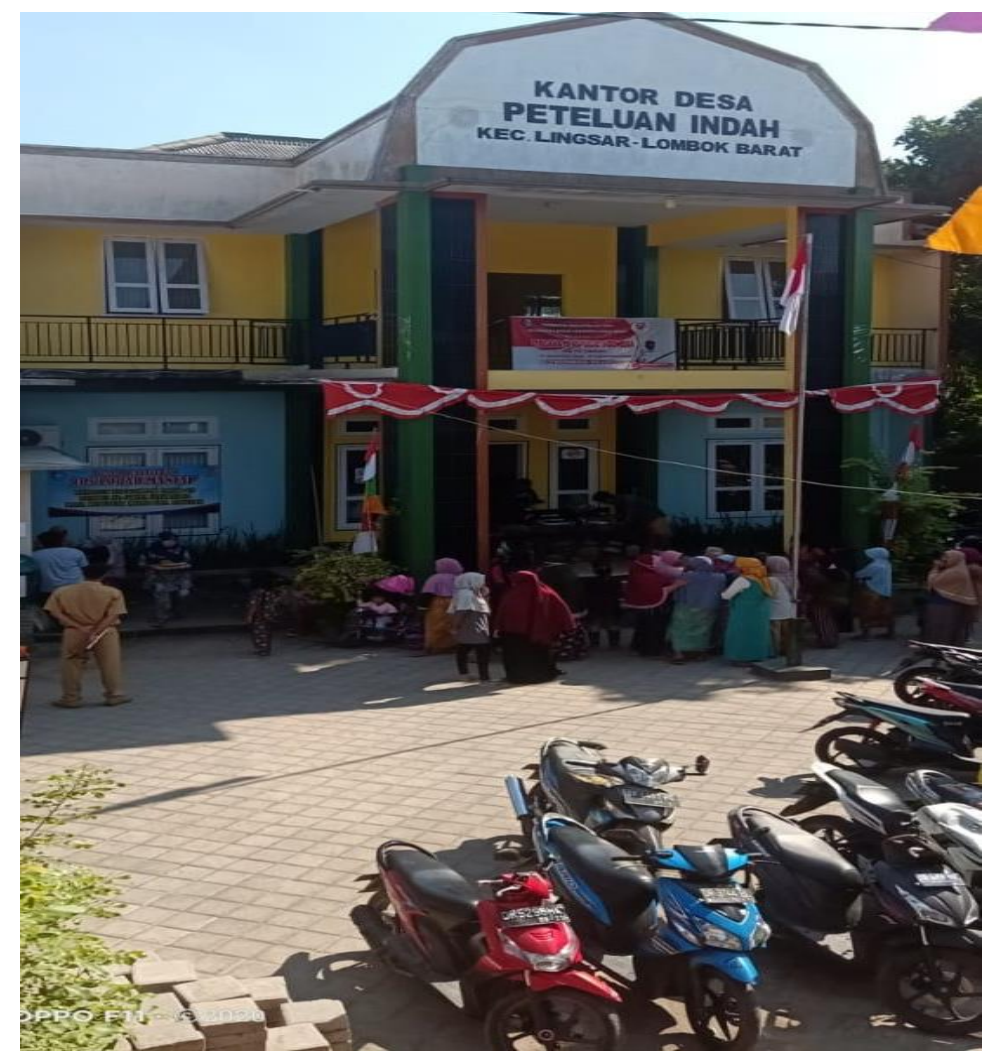

Gambar 1. Aktivitas Masyarakat Pada Kantor Desa Peteluan Indah

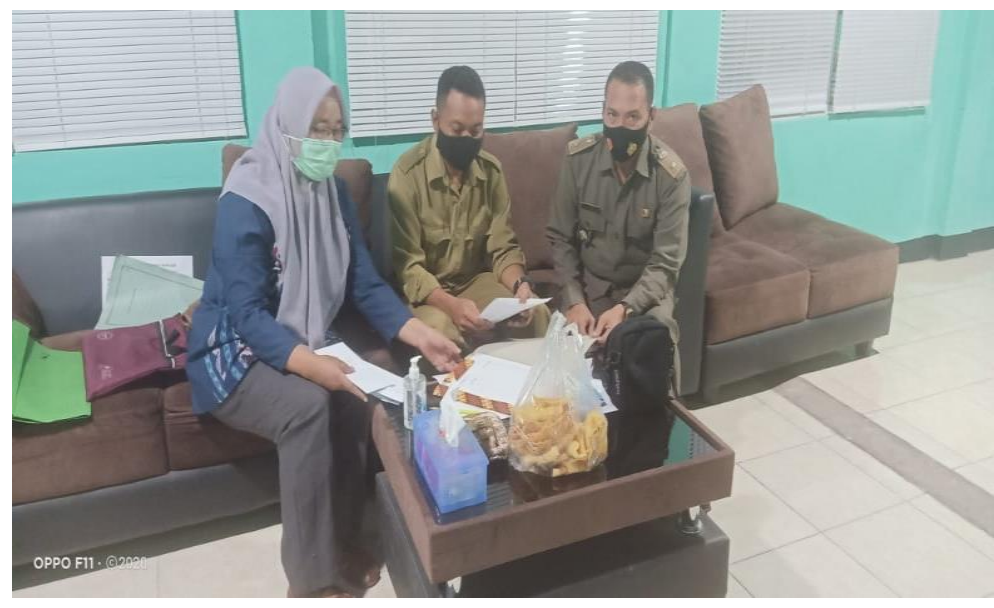

Gambar 2. Diskusi tentang potensi BUMDes dengan Perangkat Desa Peteluan Indah 
Berdasarkan hasil pembahasan dengan pemangku kepentingan desa dapat dirumuskan beberapa faktor kunci yang penting untuk dipertimbangkan dalam kegiatan BUMDes sebagai berikut:

1. Dalam menyusun kegiatan ekonomi produktif, desa harus melibatkan pemangku kepentingan desa dan menyerap aspirasi kelompok masyarakat desa secara luas sehingga keberadaannya dapat didukung oleh masyarakat desa.

2. Desa perlu membuat usaha yang bersifat pemberdayaan ekonomi masyarakat seperti BUMDes yang melibatkan peran aktif dan partisipasi dari seluruh masyarakat.

3. Bentuk rancangan kegiatan bisnis (business plan) BUMDes sebaiknya dibuat sesuai dengan potensi yang dimiliki oleh desa, baik potensi kawasan desa, kesesuaian dengan mata pencarian masyarakat, kekhasan budaya masyarakat desa setempat, keragaman kuliner makanan dan minuman khas maupun keunggulan lain yang dimiliki oleh desa.

4. BUMDes yang dibuat bukan merupakan usaha jangka pendek yang bersifat musiman, tetapi harus merupakan peluang usaha yang dapat berlangsung dalam jangka panjang yang bisa memberikan kontribusi bagi kesejahteraan ekonomi masyarakat desa secara luas.

5. Bagi BUMDes yang telah terbentuk sebelumnya tetapi mengalami kendala dalam kegiatan operasional perlu dilakukan pembinaan melalui pelatihan manajemen usaha dan pengelolaan keuangan maupun pemasaran produk.

6. Perlu dilakukan tindakan evalusi secara berkala untuk mengukur keberhasilan BUMDes serta mengetahui permasalahan dan kendala operasional yang ada sehingga ke depan dapat semakin mengoptimalkan kinerja BUMDes untuk menunjang pemberdayaan ekonomi masyarakat desa.

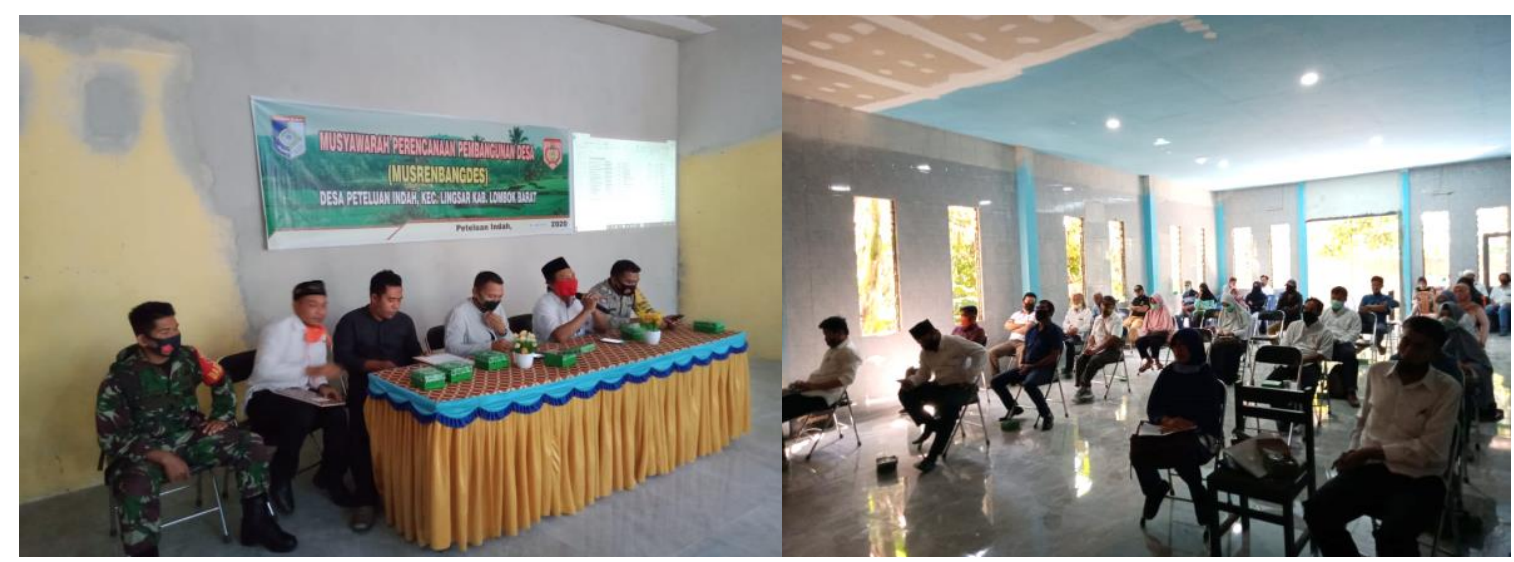

Gambar 3. Kegiatan Musyawarah Perencanaan Pembangunan Desa (Musrenbangdes)

\section{Perumusan kegiatan-kegiatan Usaha Prioritas yang Dilakukan Melalui BUMDes}

Hasil dari kegiatan pengabdian masyarakat kemitraan ini dapat mengidentifikasi rencana bisnis yang dapat ditindaklanjuti sebagai usaha BUMDes pada Desa Peteluan Indah. Rencana bisnis BUMDes yang dibuat telah mempertimbangkan potensi yang dimiliki oleh desa dan kebutuhan masyarakat. Dalam tahapan ini berhasil diinventarisasi daftar rencana kegiatan BUMDes yang berpeluang dapat dilakukan dan selanjutnya ditentukan rencana prioritas untuk kegiatan yang ditindaklanjuti. Selain itu, juga dapat diidentifikasi faktor-faktor penting dalam mendukung keberhasilan BUMDes serta kendala dan hambatan yang harus dapat diantisipasi baik untuk pembentukan BUMDes maupun dalam aspek pengelolaan. 
Daftar usaha BUMDes yang dapat diidentifikasi dan dikembangkan sebagai rencana bisnis pada Desa Peteluan Indah antara lain adalah wisata alam, wisata kuliner, peternakan, home industri/industri rumah tangga, koperasi, usaha perdagangan/toserba, layanan jasa dan kerajinan. Namun demikian dari daftar rencana bisnis tersebut perlu penentuan prioritas usaha yang akan ditindaklanjuti karena mayoritas pemangku kepentingan desa dan masyarakat menginginkan beberapa usaha prioritas untuk dijalankan. Berdasarkan skala prioritas usaha BUMDEs yang dapat ditindaklanjuti berturut-turut adalah: (1) usaha perikanan /kolam pemancingan; (2) usaha pemasaran dan distribusi pupuk/pakan ikan; (3) usaha lembaga keuangan desa (LKD) sebagai penunjang dan pendukung kegiatan ekonomi masyarakat dalam bidang perikanan/perkebunan/pertanian dan perdagangan; serta (4) usaha perdagangan/toko serba ada (seperti BUMDES mart). Muncul juga gagasan untuk mengembangkan usaha pendukung BUMDes lainnya seperti : (1) pemasaran produk hasil industri rumahan (home industry); (2) usaha penyewaan peralatan, aset desa, ruko/kios; (3) usaha kerajian khas desa; (3) rest area dan kuliner; serta usaha sosial (layanan air minum desa, listrik desa) maupun gagasan tentang pembentukan desa ekowisata/desa wisata.

Dari kegiatan pengabdian masyarakat ini dapat direkomendasikan faktor pendukung keberhasilan BUMDes yang harus dipersiapkan dengan baik seperti : (1) kemampuan Sumberdaya Manusia (SDM); (2) komitmen pimpinan desa dan pengelola BUMDES; (3) kemampuan mengelola usaha (termasuk pemasaran dan pengembangan usaha ke depan); (4) kemampuan dalam pengelolaan dan pertanggungjawaban keuangan serta (5) kontinuitas / keberlanjutan usaha. Namun demikian hambatan dan kendala dalam pembentukan dan pengelolaan BUMDes juga perlu diantisipasi seperti : (1) kurang terciptanya komunikasi yang transparan antara pimpinan desa dan masyarakat tentang BUMDES; $\quad$ (2) kurangnya akses promosi dan pemasaran; (3) keterbatasan sumberdaya manusia (SDM) yang profesional; (4) kemampuan manajemen usaha BUMDES yang kurang memadai; (5) komitmen pengelola yang kuat untuk keberlanjutan BUMDES; serta (6) kurangnya kemampuan dalam pengelolaan dan pertanggungjawaban keuangan BUMDES serta terbatasnya kemampuan dalam administrasi usaha.

Ke depan perlu dipersiapkan faktor pendukung dalam pembentukan rencana usaha BUMDes dan mengoptimalkan usaha BUMDes yang telah berjalan dengan melakukan pelatihan manajemen usaha BUMDES, pelatihan pengelolaan dan pertanggungjawaban keuangan BUMDES, pelatihan penggunaan Teknologi dan Informasi bagi pengelola BUMDES untuk mengantisipasi transformasi digital. Selain itu perlu komitmen dan dukungan dari kepada desa dan aparat serta masyarakat untuk optimalisasi peran BUMDes, pelatihan manajemen usaha dan transparansi pengelolaan keuangan BUMDES dan kebutuhan alokasi dana-dana pengembangan BUMDES. Dengan demikian pengelolaan usaha BUMDes dapat berjalan sesuai dengan tujuan yang diharapkan untuk pemberdayaan ekonomi masyarakat desa.

\section{KESIMPULAN DAN SARAN}

\section{Kesimpulan}

Kegiatan pengabdian kemitraan ini dilaksanakan dengan melakukan survey terhadap potensi unggulan desa, diskusi dalam forum pertemuan desa dan perumusan rencana usaha BUMDes. Hasil kegiatan ini dapat memberikan pengetahuan dan pemahaman kepada para pemangku kepentingan desa tentang pembentukan BUMDes sesuai dengan potensi yang dimiliki desa. Selain itu, hasil kegiatan ini juga dapat mengidentifikasi dan merumuskan bentuk usaha BUMDes sesuai dengan 
potensi unggulan desa dan kebutuhan masyarakat serta dapat merumuskan prioritas rencana bisnis BUMDes. Dengan demikian melalui rancangan usaha bisnis BUMDes yang mengakomodir potensi desa dengan menyerap aspirasi dari para pemangku kepentingan desa dan kelompok masyarakat diharapkan dapat memberdayakan ekonomi masyarakat desa dan memberikan kontribusi kesejahteraan bagi masyarakat desa secara luas.

Saran

Agar rancangan usaha BUMDes secara operasional dapat dijalankan dengan baik maka diperlukan komitmen yang kuat dari pimpinan desa dan pemangku kepentingan desa. Keberhasilan pelaksanaan rencana usaha BUMDes ini perlu didukung juga oleh kemampuan manajemen usaha dan pengelolaan keuangan bagi SDM pengelola BUMDes untuk menjamin kontinuitas dan keberlanjutan usaha di masa mendatang. Untuk menjamin dan mempertahankan agar usaha BUMDes ini dapat survive di masa mendatang maka diperlukan pelatihan dan pendampingan yang berkaitan dengan pembenahan administrasi, manajemen usaha serta transparansi dalam pengelolaan keuangan.

\section{UCAPAN TERIMA KASIH}

Ucapan terima kasih diberikan disampaikan kepada Lembaga Penelitian dan Pengabdian Masyarakat Universitas Mataram, yang telah memberikan dukungan dana untuk melaksanakan kegiatan pengabdian masyarakat mellaui Dana DIPA BLU (PNBP) Universitas Mataram tahun Anggaran 2020.

\section{DAFTAR PUSTAKA}

Agunggunanto, E.Y., Arianti, F., Kushartono, E.W \& Darwanto. (2016). Pengembangan Desa Mandiri Melalui Pengelolaan Badan Usaha Milik Desa (BUMDES). Jurnal Dinamika Ekonomi dan Bisnis, 13(7) : 67-81.

Anggareni, M.R.R.S. (2016). Peranan Badan Usaha Milik Desa (BUMDES) pada Kesejahteraan Masyarakat Pedesaan Studi ada BUMDes di Gunung Kidul, Yogyakarta. Modus, 28(2) : 155-167.

Ariyanto. (2019). Begini Cara Mengelola BUMDES yang Benar. https://blog.bumdes.id/2019/05/begini-cara-mengelola-bumdes-yang-baik-dan-benar.

Diakses pada 26 Maret 2021

Purnamasari, N. (2016). Manfaat Badan Usaha Milik Desa (BUM Desa) bagi Masyarakat. http://www.keuangandesa.com/2016/05/manfaat-badan-usaha-milik-desa-bum-desa-bagimasyarakat/ Diakses pada 25 Februari 2020.

Rahmawati, E. (2020). Analisis Pengelolaan Badan Usaha Milik Desa (BUM Desa) di Kabupaten Bandung Barat. Jurnal Ilmiah Ekonomi Bisnis, 25(1) : 1-13

Ramadana, C.B. (2013). Keberadaan Badan Usaha Milik Desa (BUMDes) Sebagai Penguatan Ekonomi Desa. Jurnal Administrasi Publik, 1(6): 1068-1076

Setyobakti, M.H. 2017. Identification of Business Enterprises BUMDES Based on Social and Economic Aspect (Case Study at BUMDes ljen Lestari Tamansari Village District of Banyuwangi). Jurnal Imliah Bidang Akuntansi dan Manajemen, 14(2) : 101-110 